\title{
The Effect of Mathematical Language On Learning Mathematics
}

\author{
Priska Wahyuni*, Saka Aji Pangestu, Itsna Shalihatus Sabila Mursyida, Aji Pangestu \\ Mathematics Education Departement, Faculty of Mathematics and Natural Science, Universitas Negeri Yogyakarta, \\ Jl. Colombo No. 1, Daerah Istimewa Yogyakarta 55281, Indonesia. Telp. +62-274-586168, Fax. +62-274-565500. \\ Email*: priskawahyuni.2017@student.uny.ac.id
}

\begin{abstract}
Language as a communication tool has an important role in interaction between human beings. Language can be used by humans to convey ideas, ideas, desires, feelings and experiences to others. Especially in a learning activity where communication tools such as language must be clearly and easily understood. In learning mathematics, the language of mathematics is very important in helping the learning process. Because to understand mathematical concepts easily requires mathematical language skills. However, the situation on the ground shows that students' understanding of mathematical language is not optimal. This study aims to determine the effect of students' mathematical language on understanding material. So the results of this study can be used by teachers as a reference in teaching mathematics to students and teachers become more concerned with students' mathematical language abilities. The method used in this study is the study of literature, which examines relevant previous studies and concludes based on the results obtained. The results of this study are that if students have understood the language of mathematics well, students can receive and understand the material easily and can increase student interest in learning. So indirectly high mathematical language skills can improve students' mathematical ideas to be more structured and convincing. Moreover, on material related to many symbols such as algebra. In addition, students can receive and understand the material easily and student interest in learning will increase.
\end{abstract}

Keywords: mathematical language, mathematics learning

\section{INTRODUCTION}

Humans are social creatures. As social beings, humans need language. As a result, language becomes an important component in life. Language activity is a characteristic of humans; through human language can carry out reflection and freedom (Chauchard in Mustansyir, 1995). Through language also humans can express all things. Language will always be used and will never be separated from human life.

According to Ferdinand de Saussure in Lyons in Suyitno (2016) language can mean concepts and can mean practical language that is used daily. Language in the sense of a concept means that a sentence consisting of a group of words each has meaning. For example, the word motor refers to the meaning of a two-wheeled vehicle.

Language can also be interpreted as many things in one word. For example, "style" in physics is different from "style" in everyday language. This kind of thing that raises ambiguity in language. Therefore, it is necessary to add terms in the language. Because this article is related to mathematics, what will be discussed this time is the language of mathematics.

The language of mathematics is related to concepts and symbols in mathematics. The language of mathematics is very important to understand because the language of mathematics is an important element in learning mathematics. Because the language of mathematics can help students in understanding mathematics. Elements in mathematical language include symbols, concepts, definitions and theorems (Ilany \& Margolin, 2010).

However, in reality students have difficulty in understanding these elements including using definitions of mathematical terms and related concepts (Mulwa, 2014), formulating mathematical models, transforming problems into mathematical equations (Jupri \& Drijvers, 2016). Students have difficulty in determining the operations that must be carried out to find solutions because they are unable to make appropriate mathematical models (Cruz \& Lapinid, 2014; Njagi, 2015). In fact, we know that the difficulties experienced by many students are very important in the process of student understanding of the material. There are several factors that can cause students difficulty understanding mathematical language including complex mathematical forms and students feel less familiar with the words they learn. That is why in learning mathematics it is very important to emphasize to students about understanding mathematical language in the form of terms, logical relationships, and mathematical symbols. Mathematical learning activities will be difficult because the object discussed is abstract and will affect in terms of expressing the object being discussed.

Many teachers today are still ignorant of the problem of mathematical language. Like, do not describe the meaning of a symbol. So students are confused in understanding a theorem. Of course, this is one example. There are still many other problems with the language of mathematics, but teachers ignore it. For this reason, this study aims to determine the effect of mathematical 
language on mathematics learning. In addition, this study is also useful for teachers to pay more attention to issues regarding mathematical language. So that teachers are more observant of students' problems.

\section{MATERIALS AND METHODS}

\section{Procedures}

The method used in this research is the study of literature, namely by reviewing relevant previous studies and concluding based on the results obtained. The process of selecting literature is carried out with 4 procedures according to Taylor. These procedures are, (1) Organize, organize literature that will be reviewed / reviewed relevant / in accordance with the problem. The stage in organizing literature is to look for ideas, an overview, and conclusions from the literature by reading abstracts, introductory paragraphs, and conclusions, and grouping the literature according to certain categories; (2) Synthesize, which unites the results of the organization of literature into a summary in order to become a unified unity, by looking for connections between literatue; (3) Identify, i.e. identify controversy issues in the literature which are considered very important to be analyzed in order to find an interesting writing to read; and (4) Formulate, namely formulating questions that require further research.

\section{RESULTS AND DISCUSSION}

\section{Mathematical Language}

Language is words or pronunciation that can be understood by humans. Language as a communication tool has an important role in interaction between human beings. Language can be used by humans to convey ideas, ideas, desires, feelings and experiences to others. Especially in a learning activity where communication tools such as language must be clearly and easily understood. According to Nordquiat in Suyitno (2016) language is a human communication system that uses signs such as sound, gestures or written symbols. Language is a social institution and a value system at the same time (Barthes, 2017). From these sources we know that language is closely related to communication systems that use signs in the form of symbols and have values. Language is (1) a systematic means of communication by users of conventional sounds or symbols, (2) a word system that is used specifically in discipline, and (3) a set of sentences (limited or unlimited), each of which has a limited length and is built from a limited set element.

According to Fitch in Even \& Newson in Suyitno (2016) mathematics is a collection of theories that are deductive in nature, each theory is a particular system of unexplained base understanding, symbols and starting points of thought that are not proven, but subject (axioms or postulates) and theorems that can be derived logically which merely follows deductive processes). Mathematics is a collection of hypothetical deductive theories with abstract objects, where each theory is a particular system that contains the basic understanding (unexplained meaning), symbols, axioms or postulates (starting points of thought in the form of statements that are the truth is not necessary), and logically derived theorems that merely follow deductive processes (Suyitno, 2016). So that we can understand that mathematics is a collection of several theories that are deductive hypotheses in which contain symbols, axioms, theorems, and postulates that can be derived logically following their deductive processes.

Mathematical language is the language used by humans to communicate ideas or ideas about mathematics between them. Mathematical languages consist of natural languages using technical terms and grammatical conventions that are specific to mathematical discourse, plus symbolic notations that are very specific to mathematical formulas. The syntax of mathematical language includes a list of symbols, configuration of rules for constructing language patterns, axioms, deductive systems, and theorems. Mathematical terms and symbols are clearly defined. Likewise, each statement in mathematical language has only one meaning or is not ambiguous. Each mathematical pattern has one structure that is determined by operational rules (Ilany \& Margolin, 2010). From this statement, an outline can be drawn that the importance of a mathematical language in the communication process (understanding) of students. When a student understands a mathematical concept and symbol, then he will be easier to convey his ideas or ideas both in writing and orally.

Good mathematical language skills require a strong base of vocabulary knowledge; flexibility; fluency and ability to understand numbers, symbols and sentences (Riccomini et al., 2015). Specifically, in relation to mathematical language, the ability to use words, explain, justify, and communicate mathematically is important for the overall development of mathematical abilities (Riccomini, P. J et al., 2015). When students understand a mathematical concept, it is high how they can convey it and one of them is by communicating using mathematical language which is already understood and understood by the object the student is aiming for. Because no matter how good the ideas obtained, it will not be meaningful if the originator of the idea is not able to communicate it. In this case needed a strong ability and foundation. The function of mathematical language is to communicate mathematical information appropriately.

Based on research conducted by (Dina, 2018) reviewing mathematical language from the semiotic and syntactic aspects. Semiotics is the study of signs. 
Semiotics, signs can be in the form of words, images, sounds, gestures and objects (Chandler, 2007). From these two aspects it can be taken a relationship that in mathematics there is a symbol such as signs, images, and sounds that are connected to each other into a word, phrase, or clause so that students more easily understand the material. In mathematics the signs often studied are pictures and objects. Syntax studies the relationship between one word and another, or other elements as a whole. The syntactic unit consists of words, phrases, clauses, sentences and discourse (Chaer, 2007). The syntactic unit observed in this research reference focuses on the vocabulary and sentences used. Based on a review of the semiotic and syntactic aspects, the reference to this research more specifically uses the following indicators to explore understanding of the language of mathematics.

Table 1. Description of Schleppegrell, (2007) on Reading \& Writing Quarterly : Overcoming Learning Difficulties The Linguistic Challenges of Mathematics Teaching and Learning: A Research Review, (October 2012), 37-41.

Indicators of Understanding Mathematical Languages

\begin{tabular}{cl}
\hline No. & \multicolumn{1}{c}{ Indikator } \\
\hline 1. & Menggunakan beberapa daftar semiotik berikut dengan tepat \\
& - Notasi simbol matematis \\
& - Grafik dan tampilan visual \\
\hline 2. & Menggunakan pola gramatikal yang tepat ditinjau dari \\
& - Kosakata teknis \\
& - Hubungan logis implisit
\end{tabular}

The semiotic list consists of mathematical symbol notations and graphics or visual displays. Symbols have characteristics that can be viewed from aspects of materiality, syntax and meaning. Graphs are an example of visual appearance in mathematics. There are also several other visual displays that can be used in understanding mathematical concepts. In mathematics the choice of visual appearance is related to what is to be expressed (Diezmann, 2008). The visual display can represent some of the things that will be conveyed, such as one example of a visual display such as images of wake-ups and space.

The word is a small unit of a sentence (Papandropoulou \& Sinclair, 1974). Sentences can be interpreted in three understandings, namely sentences as expressions with certain structures or forms, sentences as expressions with certain contexts or meanings, and sentences as specific uses (Stainton, 2000). Sentences in mathematics can be definitions, theorems or other statements containing elements of logic. Logical sentences can be in the form of implications, biimplications, negations or office sentences. Mathematical logic sentences must be proven true (Hernadi, 2008). Thus, a sentence 6 has an implicit logical relationship if the sentence is in accordance with the rules of logic.

\section{Mathematical Symbols}

According to Ernst in Sumaryono in Suyitno (2016) humans are creatures that use symbols. Symbols are used to exchange ideas and information. Symbols are needed so that ideas or information can be conveyed carefully, concisely, efficiently, and do not have multiple meanings. There are various ways to give symbols to an object, some are natural, some are through agreement. In mathematics, the determination of symbols is based on agreement. Mathematics is a symbolic language that states a problem and its solution. Based on the references of this research, symbols have characteristics that can be reviewed in terms of materiality, syntax and meaning. Materially, symbols can be in the form of Latin uruf, operators or physical attributes. In addition, the symbol syntax states the position and conventions associated with it. For example the "=" sign is used to express the same value on both sides. In meaning, symbols are placed on the domain that states the context of a problem (Pierce \& Begg, 2017). The meaning of mathematical symbols is also expressed by Serfati (2005) which states that mathematical symbols consist of three categories, namely letters, figures and other templates that combine letters and other figures in two dimensions. Symbols in the form of letters such as a, $A, \propto, \mathbb{R}, \pi$. The symbols in the form of figures such as $+, \%, \sqrt{ }, \int,=$. Symbols in the form of combined templates such as $\iint(x, y) d x d y$ (Bardini \& Pierce, 2015). The function of symbol systems in mathematics is as a communication tool (Tymoczko, 1986). The symbol functions according to Rubenstein and Thompson, 2001 are:

Table 2. Description of Rheta N. Rubenstein and Denisse R. Thompson (2001) on Learning Mathematical Symbolism: Challenges and Instructional Strategies.

\begin{tabular}{ll}
\hline \multicolumn{1}{c}{ Uses of Mathematical Symbols } \\
\hline Use & \multicolumn{1}{c}{ Examples } \\
\hline 1. Name a concept. & Number: $24,2 / 3,0.85,-5,29 \%, 4: 5, \pi, e, i$ \\
& Algebra and calculus: $x, f(x),(-4,5], \infty$ \\
& Geometry and measurement: $\angle A, \triangle A B C, E F$ \\
& Statistics and probability: $x, \chi^{2}$ \\
& Discrete mathematics: $\varnothing, \boldsymbol{N}_{0}$ \\
\hline 2. State a relationship. & Number: $2.3 \neq 2.5,3<7,5.99=6,3 \mid 12$. \\
& Algebra and calculus: $2 x+x=3 x$. \\
& Geometry and measurement: $\triangle A B C \sim \triangle R S T$ \\
& In isosceles $\triangle E F G, E F \equiv \overline{G F}$ can \\
& be shown visually, as well as \\
& symbolically. \\
& \\
& Statistics and probability: $P(X)<P(Y)$. \\
& Discrete mathematics: $A \subset B$
\end{tabular}




\section{Understanding Mathematical Concepts}

When a mathematical concept is given by the teacher through an explanation, then at the same time there is a transformation of the concept. The concept is an element of a mathematical system that communicates understanding or explains something and can also be a method, is abstract. The function concept in mathematics is to help understand something (Suyitno, 2016). According to Hamalik (2008: 166) to find out whether students already know and understand a concept, there are at least 4 things that have been done, namely as follows: 1) he can name the examples of concepts when he sees it, 2) he can state the characteristics -the characteristics of the concept, 3) he can choose, distinguish between examples from non-examples, 4) he might be better able to solve with respect to mathematical concepts.

\section{Discussion}

Mathematics is a subject that requires more understanding of the material in it. In the material there are many concepts that they must understand to be able to solve a problem. Students can be said to understand the mathematical concept if the student can communicate and distinguish one object from another or can distinguish true objects from incorrect ones. So that in the minds of students formed two sets of objects, namely the right object and the wrong object. To express a concept, a symbol is needed to make it easier for students to recognize the concept. The symbol itself can function as a communication tool, record knowledge, form new concepts, and make various classifications for easy understanding. Symbols are also useful for conveying an idea or information so that ideas can be conveyed carefully, efficiently, precisely, and do not mean multiple. In order for students to understand easily, the use of symbols must be consistent in their delivery. In this case mathematical symbols and concepts are components of mathematical language where the mathematical language functions as a communication tool, the delivery of ideas or ideas, and communicating mathematical information appropriately. So when students have mastered the language of mathematics, these students will be easier in understanding mathematical material.

\section{CONCLUSION}

In mathematics the emphasis on language skills is the real answer, because through language skills can foster meaningfulness of concepts intended by mathematics itself. So that someone will be easier in understanding the material and solving mathematical problems they face.

\section{REFERENCES}

Astuti, A., \& Leonard. (2012). Peran Kemampuan Komunikasi Matematika terhadap Prestasi Belajar Matematika Siswa. Jurnal Formatif, 2(2), 102-110

Bardini, C., \& Pierce, R. (2015). Assumed Mathematics Knowledge: The Challenge of Symbols. International Journal of Innovation in Science and Mathematics Education, 23(1), $1-9$.

Chaer, A. (2007). Linguistik Umum (Cetakan ke). Jakarta: Rianeka Cipta.

Chandler, D. (2007). Semiotics the Basics, Second Edition. London and New York: Routledge.

Cruz, J. K. B. Dela, \& Lapinid, M. R. C. (2014). Students' Difficulties in Translating Worded Problems into Mathematical Symbols. In DLSU Research Congres (pp. 17).

Diezmann, C. (2008). Graphics and the National Numeracy Tests. In 31st Annual Conference of the Mathematics Education Research Group of Australasia. Mathematics Education Research Group of Australasia Inc.

Geoffrey Leech, Margaret Deuchar and Robert Hoogenraad, English Grammar for Today, Macmillan Press LTD, 1982digunakan secara khusus Disiplin

Handayani, S. D. (2016). Pengaruh Konsep Diri dan Kecemasan Siswa Terhadap Pemahaman Konsep Matematika. Formatif: Jurnal Ilmiah Pendidikan MIPA, 6(1).

Hernadi, J. (2008). Metoda Pembuktian dalam Matematika. Jurnal Pendidikan Matematika, 2(1), 1-13.

Ilany, B.-S., \& Margolin, B. (2010). Language and Mathematics: Bridging between Natural Language and Mathematical Language in Solving Problems in Mathematics. Creative Education, 1(3), 138-148. https://doi.org/10.4236/ce.2010.13022

Jupri, A., \& Drijvers, P. (2016). Student Difficulties in Mathematizing Word Problems in Algebra. Eurasia Jurnal of Mathematics, Science \& Technology Education, 12(9), 24812502. https://doi.org/10.12973/eurasia.2016.1299a

Jurnal Ilmiah DIDAKTIKA Februari 2013 VOL. XIII, NO. 2, 296-317 HAKIKAT MANUSIA MENURUT PANDANGAN ISLAM DAN BARAT Siti Khasinah Dosen Fakultas Tarbiyah IAIN Ar-Raniry Banda Aceh

Mahmudi, A. (2006). Pengembangan kemampuan komunikasi matematika siswa melalui pembelajaran matematika. SEMNAS Matematika dan Pendidikan Matematika, 10, 175182.

Mulwa, E. C. (2014). The Role of the Language of Mathematics in Students' Understanding of Number Concepts in Eldoret Municipality, Kenya. International Journal of Humanities and Social Science, 4(3), 264-274.

Mustansyir, Rizal. (1995). Bhinneka Tunggal Ika dalam Perspektif Filsafat Analitik. Jurnal Filsafat Agustus '95

NCTM. 2005. Curriculum and Content Area Standards. Mathematical Standards. http://cnets.iste.org/currstands/cstands-m.html. 26 Maret 2006

Njagi, M. W. (2015). Language Issues on Mathematics Achievement. International Journal of Education and Research, 3(6), 167-178.

Papandropoulou, I., \& Sinclair, H. (1974). What is a Word? Human Develop, 17, 241- 258. 
Pierce, R., \& Begg, M. (2017). First Year University Students' Difficulties with Mathematical Symbols: The Lecturer/Tutor Perspective. 40 Years on: We Are Still Learning! (Proceedings of the 40th Annual Conference of the Mathematics Education Research Group of Australasia) Pp., (July).

Pramono, T. (2012). Keefektifan Belajar Matematika melalui Pemahaman Kalimat dan bahasa simbol. UPBJJ-UT Yogyakarta, 37(1), 1-15.

Riccomini, P. J., Smith, G. W., Hughes, E., \& Fries, K. M. (2015). The Language of Mathematics: The Importance of Teaching and Learning Mathematical Vocabulary. Reading \& Writing Quarterly, $31(3)$ $235-252$. https://doi.org/10.1080/10573569.2015.1030995

Schleppegrell, M. J. (2007). Reading \& Writing Quarterly: Overcoming Learning Difficulties The Linguistic Challenges of Mathematics Teaching and Learning: A Research Review, (October 2012), 37-41.
Serfati, M. (2005). La Revolution Symbolique: La Constitution de l'Ecriture Symbolique Mathematique. Philosophia Mathematica.

Sruiasumantri, Jujun S. 2001. Filsafat Ilmu Sebuah Pengantar Populer. Jakarta: Pustaka Sinar Harapan

Stainton, R. J. (2000). The Meaning of "Sentences." Nous, 34(3), 441-454. https://doi.org/10.1111/0029-4624.00219

Sumarmo, 1994. Suatu Alternatif Pengajaran untuk Meningkatkan Kemampuan Komunikasi Matematika Pada Guru dan Siswa SMP.Laporan penelitian IKIP Bandung. Bandung: Tidak diterbitkan

Suyitno, Hardi. (2016). Pengantar Filsafat Matematika. Yogyakarta: Magnum Pustaka Utama

Taylor, Dena The Literature Review: A Few Tips On Conducting It diambil dari http://advice.writing.utoronto.ca/types-ofwriting/literature-review/ 
THIS PAGE INTENTIONALLY LEFT BLANK 